\title{
The evolution and degradation of coastal and offshore permafrost in the Laptev and \\ Eastern Siberian seas during the last climatic cycle
}

Pier Paul Overduin ${ }^{1}$, Hans-W. Hubberten ${ }^{1}$, Volker Rachold ${ }^{2}$, Nikolai Romanovskii ${ }^{3}$, Mikhail Grigoriev ${ }^{4}$, Maria $^{2}$ Kasymskaya $^{3}$

\section{ABSTRACT}

We investigate the fate of permafrost since the last glacial maximum in the East Siberian Seas, a submergent coastal environment. The shelf here is up to $700 \mathrm{~km}$ wide and less than $80 \mathrm{~m}$ deep, so that a large area is highly sensitive to changes in environmental conditions. Climate and sea level histories, and the terrestrial and coastal geomorphology of the region are combined with direct observations from drilling campaigns to review existing notions on the distribution, thickness, physical state, and history of the development of terrestrial and offshore permafrost since the last glacial maximum. Drilling transects running perpendicular to the coast in the near-shore zone show that the interface between unfrozen and frozen sediments varies in its angle of inclination as a result of a number of factors primarily including coastal retreat rate. A conceptual model of permafrost development prior to submergence suggest that thermokarst and near shore processes are critical in altering the development of permafrost in the submarine environment.

\section{Citation :}

Overduin, P. P., Hubberten, H. -W., Rachold, V., Romanovskii, N., Grigoriev, M. N., Kasymskaya, M. (2007). Evolution and degradation of coastal and offshore permafrost in the Laptev and East Siberian Seas during the last climatic cycle, Coastline changes : interrelation of climate and geological processes / edited by Jan Harff, William W. Hay, Daniel M. Tetzlaff Boulder, Colo : Geological Society of America, 97-111. (The Geological Society of America special paper ; 426), doi:10.1130/2007.2426(07) . Geological Society of America, P.O. Box 9140, Boulder, CO 80301-9140 USA (http://www.geosociety.org)

1. Alfred Wegener Institut für Polar- und Meeresforschung, Telegrafenberg A43, 14473 Potsdam, Germany; 2. International Arctic Science Committee, 10405 Stockholm

Sweden ; 3. Department of Geology, Moscow State University, Vorobievy Gory, Moscow 119899, Russia; 4. Permafrost Institute, Siberian Branch of Russian Academy of Sciences, Merzlotnaya Street, Yakutsk 677010, Sakha, Russia 